\title{
PENGARUH PERLAKUAN ALKALI DAN VOLUME LARUTAN PENGEKSTRAK TERHADAP MUTU KARAGINAN DARI RUMPUT LAUT Eucheuma cottonii
}

\author{
Th. Dwi Suryaningrum, Murdinah dan Mei Dwi Erlina*
}

\begin{abstract}
ABSTRAK
Penelitian ekstraksi rumput laut Eucheuma cottonii menjadi karaginan kertas telah dilakukan. Penelitian dilaksanakan dengan rancangan acak lengkap dengan variasi perlakuan bahan baku yaitu rumput laut yang diberi perlakukan $\mathrm{KOH} 6 \%$ dan $8 \%$ dan volume larutan pengekstrak 60 kali dan 50 kali dari bobot rumput laut kering. Percobaan dilakukan dengan 3 kali ulangan. Ekstraksi dilakukan dengan menggunakan larutan $\mathrm{KCl} 0,1 \%$ selama 3 jam pada suhu $90-95^{\circ} \mathrm{C}$. Pengamatan dilakukan terhadap rendemen karaginan, sifat kimia (kadar air, abu, abu tak larut asam, sulfat dan 3,6-anhydrogalaktosa) dan sifat fisik (kekuatan gel dan kekentalan) karaginan yang dihasilkan. Hasil penelitian menunjukkan rumput laut yang diberi perlakuan $\mathrm{KOH} 6 \%$ menghasilkan rendemen dan kekentalan larutan karaginan yang lebih baik sedangkan perlakuan $\mathrm{KOH} 8 \%$ menghasilkan karaginan yang mempunyai kadar air, kadar abu dan kadar abu tak larut asam yang lebih baik. Perlakuan terhadap bahan baku rumput laut dan volume larutan pengekstrak tidak berpengaruh nyata terhadap kadar sulfat dan kekuatan gel yang dihasilkan. Jika rendemen dan kekuatan gel diprioritaskan maka dalam ekstraksi karaginan dapat disarankan menggunakan rumput laut yang telah diberi perlakuan $\mathrm{KOH} 6 \%$ dan diekstraksi dengan larutan $\mathrm{KCl} 0,1 \%$ selama 3 jam dengan volume larutan pengekstrak 60 kali bobot rumput laut kering.
\end{abstract}

ABSTRACT: $\quad$ The effect of alkali treatment and volume of extraction water on the quality of carrageenan from Eucheuma cottonii. By: Th. Dwi Suryaningrum, Murdinah and Mei Dwi Erlina

Study on the carrageenan extraction from Eucheuma cottonii with alkali treatment and variation of the volume of extraction water has been conducted. Completely randomized experimental design has been applied to analyze the data. Treatments observed in this study were $\mathrm{KOH}$ concentrations (6\% and $8 \%$ ) and water propotion (50 and 60 times of dry seaweed weight). The experiment was carried out in three replicates. Extraction was done by applying $0.1 \% \mathrm{KCL}$ solution for 3 hours at $90-95^{\circ} \mathrm{C}$. Yield of carrageenan, chemical parameters (moisture content, ash, acid insoluble ash, sulphate and 3.6-anhydrogalactose) and physical parameters (gel strength and viscosity), were investigated. The result showed that seaweed treated with $6 \% \mathrm{KOH}$ produced carrageenan with better yield and viscosity than that treated with $8 \% \mathrm{KOH}$ but seaweed treated with $8 \% \mathrm{KOH}$ produced carrageenan with higher moisture and ash content. Alkali treatment and water proportion did not affect sulphate content and gel strength of the extracted carrageenan. If yield and gel strength were intended to be the main factors of carrageenan quality, it is suggested that seaweed has to be treated with $6 \% \mathrm{KOH}$ and extracted with $0.1 \% \mathrm{KCL}$ for 3 hours at $90-95^{\circ} \mathrm{C}$ using extraction water 60 times of the weight of dry seaweed.

KEYWORDS : Eucheuma cottonii, physico-chemical characteristics of carrageenan.

\section{PENDAHULUAN}

Karaginan merupakan hidrokoloid hasil ekstraksi dari rumput laut merah yang merupakan senyawa polisakarida komplek. Senyawa tersebut dibangun oleh sejumlah unit galaktosa dan 3,6-anhydrogalaktosa baik yang mengandung sulfat maupun tidak dengan ikatan alfa 1,3-D-galaktosa dan beta 1,4-3,6anhydrogalaktosa (Chaplin, 2003). Senyawa ini banyak digunakan dalam industri pangan karena kemampuannya untuk memodifikasi tekstur, cita rasa yang berhubungan dengan kelembutan dan kerenyahan, daya awet sifat emulsi produk serta mampu menstabilkan protein susu karena adanya gugus ester sulfat (Sandersen, 1981). Kebutuhan karaginan juga meningkat paling tidak $5-7 \%$ setiap tahunnya sejalan dengan kemajuan dalam bidang industri pangan, farmasi dan sanitasi karena sifatnya yang sangat unik yang tidak dapat digantikan oleh gum lainnya (Anonymous, 1996)

*) Peneliti pada Pusat Riset Pengolahan Produk dan Sosial Ekonomi Kelautan dan Perikanan 
Sebagai negara kepulauan, Indonesia mempunyai sumberdaya rumput laut penghasil karaginan yang potensial terutama untuk jenis Eucheuma cottonii dan Eucheuma spinosum penghasil kappa dan iota karaginan. Kedua jenis rumput laut tersebut telah berhasil dibudidayakan di beberapa daerah di Indonesia terutama oleh masyarakat pesisir. Tercatat pada tahun 1999 produksi rumput laut sebesar 23.152 ton dan naik menjadi 42.712 ton pada tahun 2000 (Anonymous, 2001) dan produksi tersebut cenderung meningkat setiap tahunnya. Perkiraan areal strategis yang dapat digunakan untuk budidaya rumput laut Eucheuma sp di Indonesia adalah $21.500 \mathrm{Ha}$ (Basmal, 2000). Sampai saat ini lahan tersebut belum dimanfaatkan secara optimal. Apabila lahan tersebut dimanfaatkan, maka akan tersedia sumberdaya rumput laut yang sangat melimpah. Untuk itu perlu diimbangi dengan industri pengolahan rumput laut menjadi karaginan di dalam negeri. Selama ini rumput laut diekspor dalam bentuk bahan baku atau alkali treated carrageenan (ATC). Di lain pihak Indonesia masih mengimpor karaginan untuk kebutuhan industri pangan dan non pangan.

Masalah utama yang menjadi kendala dalam pengolahan rumput laut menjadi karaginan adalah modal yang besar untuk investasinya. Dalam penelitian ini pengolahan karaginan dicoba dengan menggunakan proses seperti pada pengolahan agaragar kertas yang telah dikembangkan oleh Pusat Riset Pengolahan Produk dan Sosial Ekonomi Kelautan dan Perikanan. Diharapkan jika metode tersebut dapat diterapkan pada pengolahan karaginan maka akan diperoleh teknologi pengolahan karaginan yang lebih mudah dan murah. Dilain pihak potensi sumberdaya dan kebutuhan karaginan yang terus meningkat, membuat peluang untuk membangun industri karaginan di Indonesia cukup prospektif. Saat ini Indonesia masih tercatat sebagai negara produsen rumput laut terbesar kedua setelah Filipina. Sedangkan Filipina sendiri telah menguasai produksi karaginan dunia sebesar $43 \%$ dari total produksi karaginan yang ada (Anonymous, 2000). Melihat potensi yang ada seharusnya Indonesia dapat tercatat sebagai negara produsen karaginan seperti halnya Filipina.

Masalah lain yang dihadapi adalah rendahnya kualitas rumput laut penghasil karaginan terutama rendemen dan kekuatan gel yang dihasilkan. Untuk meningkatkan rendemen dan kekuatan gel, dalam penelitian ini digunakan perlakuan alkali panas terhadap bahan baku rumput laut. Perlakuan alkali bertujuan untuk mengkatalisis hilangnya gugus 6 sulfat yang bersifat hidrofilik dari unit monomer karaginan dan membentuk 3,6-anhydrogalaktosa yang bersifat hidrofobik sehingga dapat meningkatkan gel karaginan yang dihasilkan (Stanley, 1987). Sedangkan menurut Neish (1989), perlakuan alkali bertujuan untuk meningkatkan titik leleh karaginan di atas suhu pemasakannya, sekaligus memucatkan warna rumput laut sehingga dihasilkan karaginan yang mempunyai kekuatan gel yang tinggi dan warna karaginan yang lebih putih.

\section{BAHAN DAN METODE}

\section{Persiapan Bahan dan Peralatan}

Bahan yang digunakan dalam penelitian ini adalah rumput laut jenis Eucheuma cottonii yang diperoleh dari petani rumput laut di P. Panjang Kab. Serang, Banten. Rumput laut kemudian direbus dengan larutan $\mathrm{KOH}$ dengan konsentrasi $6 \%$ dan $8 \%$ dengan volume larutan perebus 5 kali bobot rumput laut kering dan lama perebusan 6 jam. Rumput laut kemudian dicuci berulang-ulang sehingga netral kembali dan dijemur hingga kering. Rumput laut kering yang sudah diperlakukan dengan alkali kemudian digunakan sebagai bahan untuk penelitian ekstraksi karaginan. Sedangkan bahan pembantu yang digunakan untuk ekstraksi karaginan adalah $\mathrm{KOH}$ dan $\mathrm{KCL}$ teknis.

Peralatan yang digunakan untuk mengekstraksi karaginan adalah dandang double unit untuk perebusan dengan kapasitas 200 liter, pengaduk kayu, saringan bergetar, pan penjendal, alat pengiris gel agar, kain pembungkus ukuran $40 \times 60 \mathrm{~cm}$, seperangkat alat press, para-para penjemur, dan mesin penepung

\section{Penelitian Pendahuluan}

Penelitian pendahuluan dilakukan untuk mencari konsentrasi $\mathrm{KCl}$ serta lama waktu perebusan pada skala laboratorium. Konsentrasi $\mathrm{KCl}$ yang digunakan dalam percobaan ini adalah $0,1 \%, 0,2 \%$ dan $0,3 \%$, dengan lama ekstraksi mengikuti lama ekstraksi karaginan yang ada di lapangan yaitu 6 jam dengan volume larutan pengekstrak 50 kali bobot rumput laut. Pengamatan dilakukan terhadap rendemen yang dihasilkan. Konsentrasi $\mathrm{KCl}$ optimum yang diperoleh digunakan untuk mencari lama waktu perebusan, yaitu 3, 6 dan 9 jam dengan volume larutan pengekstrak 50 kali bobot rumput laut yang digunakan. Pengamatan dilakukan terhadap rendemen karaginan sedangkan pengukuran kekuatan gel karaginan dilakukan terhadap perlakuan yang menghasilkan rendemen terbaik. Waktu dan konsentrasi $\mathrm{KCl}$ terbaik yang diperoleh digunakan untuk percobaan selanjutnya.

\section{Penelitian Lanjutan}

Percobaan ini merupakan lanjutan yang didasarkan dari penelitian pendahuluan. Penelitian dirancang dengan menggunakan rancangan acak lengkap dengan 
variasi perlakuan bahan baku yaitu rumput laut yang diberi perlakukan $\mathrm{KOH} 6 \%$ dan $8 \%$ serta volume larutan pengekstrak 60 kali dan 50 kali bobot rumput laut kering. Percobaan dilakukan dengan 3 kali ulangan.

Ekstraksi rumput laut dilakukan dengan cara sebagai berikut : $1 \mathrm{~kg}$ rumput laut kering yang telah diberi perlakuan $\mathrm{KOH} 6 \%$ dan $8 \%$ diekstrak dengan menggunakan larutan $\mathrm{KCl}$ dengan konsentrasi terpilih dengan volume larutan pengekstrak 50 dan 60 kali bobot rumput laut. Ekstraksi dilakukan pada suhu $90-95^{\circ} \mathrm{C}$ selama $3 \mathrm{jam}$. Setelah proses ekstraksi selesai rumput laut disaring dengan menggunakan alat saringan bergetar. Filtrat yang diperoleh ditampung dalam pan penjendal dan dibiarkan semalam untuk pembentukan gel. Gel karaginan kemudian diiris dengan menggunakan alat pemotong gel dengan ketebalan $0,8 \mathrm{~cm}$ sehingga membentuk lembaran. Lembaran gel karaginan dibungkus dengan menggunakan kain pembungkus kemudian dipres dengan menggunakan balok yang terbuat dari semen. Pengepresan dilakukan selama semalam dengan penambahan beban secara bertahap sehingga diperoleh lembaran gel karaginan yang cukup tipis dengan ketebalan sekitar 0,5-0,6 cm. Gel karaginan kemudian dijemur beserta kainnya sampai kering sehingga membentuk lembaran seperti kertas tipis. Karaginan kertas kemudian dilepaskan dari kainnya, kemudian dipotong-potong dan digiling sehingga menjadi tepung karaginan.

\section{Parameter yang Diamati}

Mutu karaginan yang diamati meliputi rendemen karaginan serta sifat kimiawi dan fisik karaginan. Uji kimiawi meliputi kadar air, kadar abu, kadar abu tak larut asam, dengan metode AOAC (1984), kadar sulfat dengan metode gravimetri (Anonymous, 1986), 3,6anhydrogalaktosa dengan metode spektrometri (Anonymous, 1977). Uji fisik meliputi kekentalan diukur dari larutan $1,5 \%(\mathrm{~b} / \mathrm{b})$ karaginan pada suhu $76-77^{\circ} \mathrm{C}$ dengan menggunakan Viskometer model BM (Ogawa Seiki Japan). Kekuatan gel diukur dari larutan karaginan $2 \%$ yang telah membentuk gel pada suhu $25^{\circ} \mathrm{C}$ semalam dengan menggunakan Curd Meter (Anonymous, 1977).

\section{HASIL DAN BAHASAN}

\section{Penelitian Pendahuluan}

Rendemen karaginan hasil ekstraksi dengan menggunakan larutan $\mathrm{KCl} 0,1,0,2$ dan $0,3 \%$ dapat dilihat pada Gambar 1. Rendemen karaginan tertinggi diperoleh dari rumput laut yang diekstrak dengan larutan $\mathrm{KCl} 0,1 \%$ yaitu sebesar $57,04 \%$. Rendemen ini jauh lebih tinggi dibandingkan dengan rendemen karaginan yang diekstrak dengan menggunakan larutan $\mathrm{KCl} 0,2 \%$ dan $0,3 \%$. Hal ini disebabkan karena semakin tinggi konsentrasi $\mathrm{KCl}$ yang digunakan semakin cepat filtrat karaginan membentuk gel. Menurut Chaplin (2003) adanya ion $\mathrm{K}^{+}$tidak saja

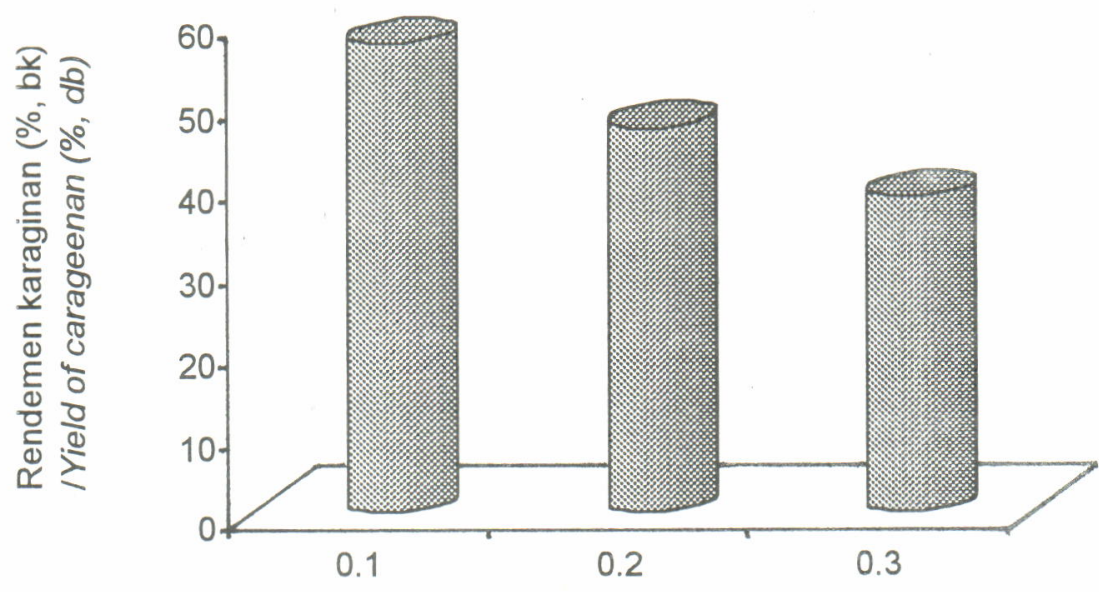

Konsentrasi KCL $/ K C L$ consentration (\%)

Gambar 1. Rendemen karaginan yang diekstrak dengan berbagai konsentrasi $\mathrm{KCl}$, waktu ekstraksi 6 jam, volume pengekstrak $50 x$ bobot rumput laut kering

Figure 1. Yield of carrageenan extracted by various concentration of $\mathrm{KCl}$, extraction time 6 hours, extraction water $50 x$ dry seaweed weight 
membantu pembentukan helik rangkap tetapi juga dalam pembentukan agregat antar helik yang membentuk jaringan 3 dimensi yang menyebabkan pembentukan gel. Kecepatan pembentukan gel ini berakibat sulitnya proses penyaringan, sehingga filtrat yang diperoleh semakin menurun yang berpengaruh terhadap rendemen yang dihasilkan.

Oleh karena itu konsentrasi $\mathrm{KCl}$ yang digunakan untuk penelitian selanjutnya adalah $0,1 \%$. Larutan pengektrak $\mathrm{KCl} 0,1 \%$ ini selanjutnya digunakan untuk mencari waktu ekstraksi karaginan yang optimum .

Gambar 2 menunjukkan rendemen karaginan yang diekstrak dengan $\mathrm{KCl} 0,1 \%$ dengan waktu ekstraksi yang berbeda. Semakin lama waktu

\section{Penelitian Lanjutan}

Pada penelitian lanjutan digunakan variabel bahan baku rumput laut yang telah direbus dengan $\mathrm{KOH}$ dengan konsentrasi $6 \%$ dan $8 \%$ dengan volume larutan pengekstrak 50 kali dan 60 kali bobot rumput laut kering. Ekstraksi dilakukan dengan larutan $\mathrm{KCl} \mathrm{0,1 \%}$ dan lama waktu ekstraksi 3 jam.

\section{Rendemen Karaginan}

Hasil analisis statistik menunjukkan bahwa perlakuan bahan mentah rumput laut dan volume larutan pengekstrak menghasilkan rendemen karaginan yang berbeda sangat nyata $(P<0,01)$. Dari

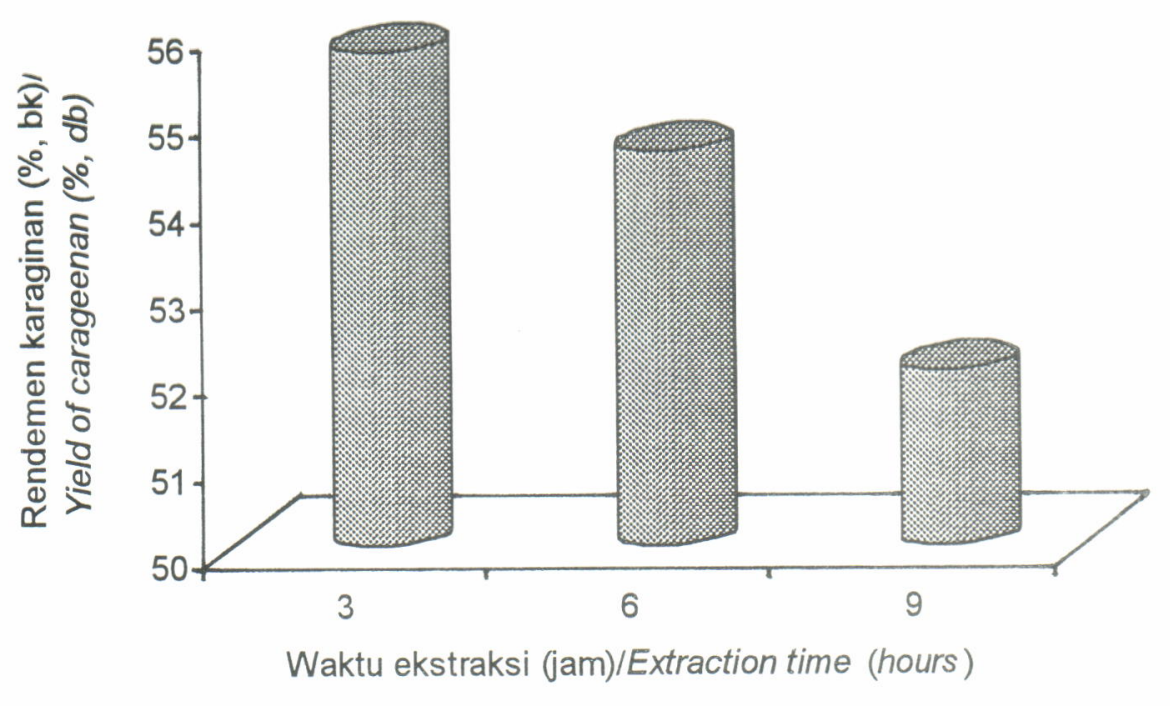

Gambar 2. Rendemen karaginan yang diekstrak dengan berbagai waktu ekstraksi, $\mathrm{KCL} 0,1 \%$, volume pengekstrak $50 x$ bobot rumput laut kering

Figure 2. Yield of carrageenan extracted at various extraction time, $K C L 0.1 \%$, extraction water $50 x$ dry seaweed weight

perebusan semakin menurun rendemen karaginan yang dihasilkan. Hal ini disebabkan karena semakin lama waktu ekstraksi semakin banyak penguapan yang menyebabkan filtrat semakin kental. Semakin kental filtrat yang diperoleh semakin cepat pula filtrat membentuk gel sehingga sukar untuk disaring. $\mathrm{Hal}$ ini berakibat pada menurunnya rendemen karaginan yang dihasilkan. Oleh karena itu dalam penelitian selanjutnya digunakan larutan ekstraksi $\mathrm{KCl} 0,1 \%$ dan waktu ekstraksi 3 jam. Adapun kekuatan gel rata-rata karaginan yang diekstrak dengan larutan $\mathrm{KCl}$ $0,1 \%$ dan waktu ekstraksi 3 jam adalah sebesar $550 \mathrm{~g} / \mathrm{cm}^{2}$.
Gambar 3 terlihat bahwa rata-rata rendemen karaginan yang diperoleh dari rumput laut yang diberi perlakuan larutan $\mathrm{KOH} 6 \%$ lebih tinggi dibandingkan dengan ratarata rendemen karaginan yang diberi perlakuan $\mathrm{KOH}$ $8 \%$. Hal ini disebabkan karaginan yang diekstrak dari rumput laut yang diberi perlakuan $\mathrm{KOH} 8 \%$ lebih kental sehingga sulit disaring dibandingkan dengan karaginan yang diekstrak dari rumput laut yang diberi perlakuan KOH 6\%. Menurut Stanley (1987) dan Neish (1989) semakin tinggi konsentrasi $\mathrm{KOH}$ yang diberikan menyebabkan dinding sel lebih cepat menggembung, sehingga lebih banyak karaginan yang keluar. Hal ini terlihat dari filtrat rumput laut yang diberi perlakuan 


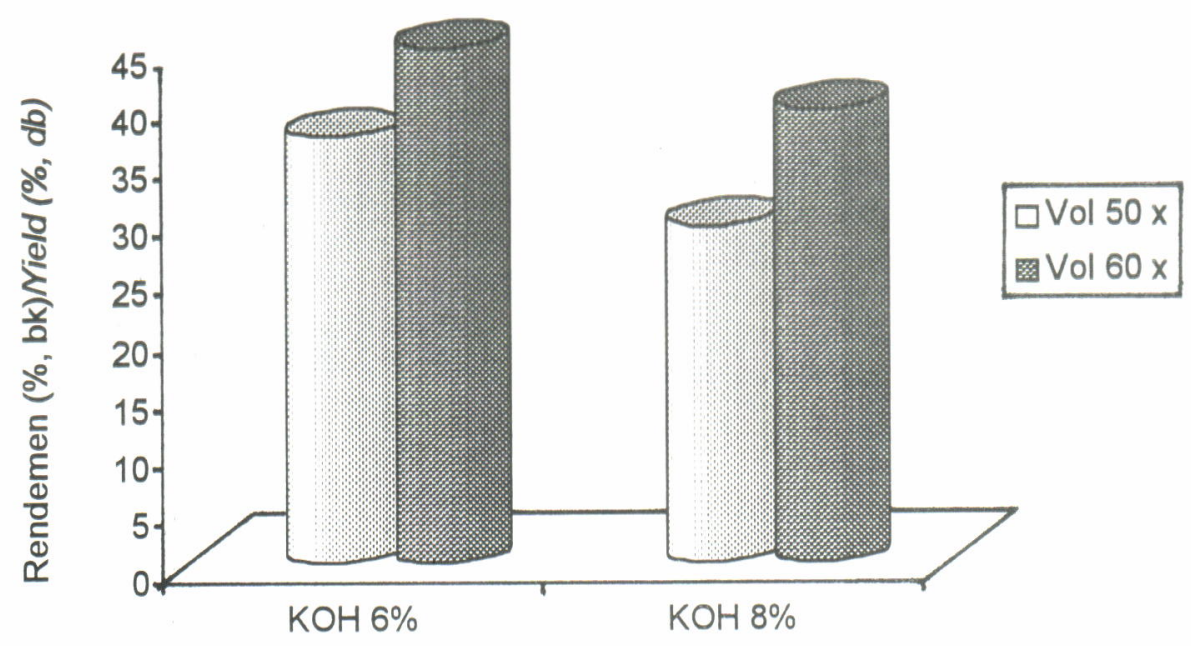

Gambar 3. Rendemen karaginan dari perlakuan konsentrasi $\mathrm{KOH}$ dan volume larutan pengekstrak yang berbeda

Figure 3. Yield of carrageenan resulted from different concentration of $\mathrm{KOH}$ and volume of extraction water

$\mathrm{KOH} 8 \%$ lebih kental dan lebih cepat membentuk gel dibandingkan dengan filtrat rumput laut yang diberi perlakuan $\mathrm{KOH} 6 \%$. Disamping itu filtrat rumput laut yang diberi perlakuan $\mathrm{KOH} 8 \%$, mempunyai titik gel dengan suhu yang lebih tinggi, sehingga ketika suhu turun larutan menjadi sangat kental. Pada penelitian ini penyaringan dilakukan dengan menggunakan saringan bergetar dimana proses penyaringannya berjalan agak lambat sehingga proses penyaringan belum selesai, filtrat sudah membentuk larutan yang sangat kental. Dengan demikian filtrat hasil penyaringan yang diperoleh dari rumput laut yang diberi perlakukan alkali $\mathrm{KOH} 8 \%$ lebih sedikit dan berpengaruh terhadap penurunan rendemen yang dihasilkan. Pada perlakuan volume larutan pengekstrak, rendemen karaginan yang diekstrak dengan volume larutan pengekstrak 60 kali bobot rumput laut lebih tinggi dibandingkan dengan volume larutan pengekstrak 50 kali. Rendemen tersebut semakin berkurang bila diekstrak dari rumput laut yang diberi perlakuan $\mathrm{KOH} 8 \%$ dengan volume larutan pengekstrak 50 kali. Hal ini karena filtrat yang diperoleh sangat kental dan pada suhu tinggi $\left(55^{\circ} \mathrm{C}\right)$ sudah membentuk gel dibandingkan dengan karaginan yang diekstrak dengan menggunakan volume larutan pengekstrak 60 kali. Ekstraksi dengan menggunakan volume 60 kali memungkinkan semakin banyak air yang terserap, sehingga dinding sel semakin mengembang dan memudahkan karaginan keluar dari dinding sel.
Semakin banyak volume larutan pengekstrak semakin banyak air yang terdispersi yang menyebabkan proses pembentukan gel terganggu. Banyaknya air yang terdispersi akan menyebabkan susunan molekul karaginan masih dalam bentuk sol tidak dalam bentuk tiga demensi atau struktur helik rangkap yang merupakan fenomena pembentukan gel (Chapman dan Chapman, 1980). Keadaan ini sangat membantu dalam proses penyaringan, walaupun suhu filtrat telah turun filtrat masih dalam bentuk cair yang mudah disaring sehingga berpengaruh pada meningkatnya rendemen karaginan yang dihasilkan. Dalam proses pengolahan karaginan, penyaringan merupakan faktor kritis yang menentukan tingkat mutu karaginan yang dihasilkan (Stanley, 1987). Semakin tinggi teknologi proses penyaringan yang digunakan, akan semakin tinggi rendemen dan mutu karaginan yang dihasilkan. Dalam industri pengolahan karaginan biasanya penyaringan dilakukan dengan menggunakan filter press dengan kain saring yang ukuran meshnya sangat kecil. Hal ini dimaksudkan agar filtrat yang tersaring semakin banyak dan karaginan yang dihasilkan tidak tercampur dengan selulose atau kotoran lain yang dapat mengganggu pembentukan gel (Chapman dan Chapman, 1980). Uji Duncan menunjukkan bahwa rendemen karaginan yang diperoleh dari bahan mentah rumput laut yang telah diberi perlakuan $\mathrm{KOH} 6 \%$ dan volume larutan pengekstrak 60 kali menghasilkan rendemen yang paling tinggi dan berbeda nyata dengan perlakuan 
lainnya. Sedangkan perlakuan rumput laut yang diberi perlakuan $\mathrm{KOH} 8 \%$ dan volume larutan pengekstrak 50 kali menghasilkan rendemen yang paling rendah

Rendemen karaginan pada percobaan ini berkisar antara $27,55-49,03 \%$ (bk). Bila dibandingkan dengan rendemen rumput laut yang belum mendapatkan perlakuan alkali yang hanya berkisar antara $15-25 \%$, rendemen yang dihasilkan ini lebih tinggi. Rumput laut yang telah diberi perlakuan alkali mempunyai sifat gel yang lebih baik bila dibandingkan dengan rumput laut yang tidak diberi perlakuan alkali.

\section{Sifat Kimia Karaginan}

\section{Kadar air}

Rata-rata kadar air tepung karaginan yang diperoleh dari penelitian ini berkisar antara 17,51$27,59 \%$. Hasil analisis statistik menunjukkan kadar air karaginan yang diekstrak dari rumput laut yang diberi perlakukan $\mathrm{KOH} 6 \%$ berbeda nyata $(P<0.01)$ bila dibandingkan dengan karaginan yang diekstrak dari rumput laut yang diberi perlakuan $\mathrm{KOH} 8 \%$. Kadar air karaginan yang diekstrak dari rumput laut yang diberi perlakukan $\mathrm{KOH} 6 \%$ lebih tinggi, baik yang diekstrak dengan volume larutan pengekstrak 50 kali maupun 60 kali (Gambar 4). Hal ini disebabkan dengan semakin tinggi konsentrasi alkali yang digunakan semakin banyak gugus sulfat yang dapat mengikat air yang hilang. Karaginan yang dihasilkan dari rumput laut yang diberi perlakuan $\mathrm{KOH} 8 \%$ kadar sulfatnya lebih rendah, sehingga tidak banyak mengikat air bila dibandingkan dengan karaginan yang diekstraksi dari rumput laut yang diberi perlakuan $\mathrm{KOH}$ $6 \%$. Oleh karena itu dengan waktu pengeringan yang sama maka karaginan yang diekstraksi dari rumput laut yang diberi perlakuan $\mathrm{KOH} 8 \%$ lebih cepat kering dibandingkan dengan karaginan yang diekstraksi dari rumput laut yang diberi perlakuan alkali $6 \%$. Demikian juga penggunaan volume larutan pengekstrak 60 kali menyebabkan lebih banyak air yang terdispersi dalam larutan karaginan. Kondisi tersebut menyebabkan pengeringan agak terhambat, sehingga dengan waktu pengeringan yang sama maka kadar air karaginan yang diekstrak dengan volume pengekstrak 60 kali lebih tinggi bila dibandingkan dengan kadar air karaginan yang diekstraksi dengan volume pengekstrak 50 kali.

Kadar air karaginan yang diperoleh dari penelitian ini masih cukup tinggi bila dibandingkan dengan syarat tepung karaginan yang dikeluarkan oleh FAO yaitu sebesar 12\% (Anonymous, 1978). Dalam penelitian ini proses pengeringan dilakukan dengan cara menjemur lembaran karaginan yang masih terbungkus dengan kain selama 3 hari pada cuaca yang cukup panas. Nampaknya pengeringan karaginan selama 3 hari belum cukup untuk mengeringkan karaginan sesuai dengan tingkat kekeringan yang telah

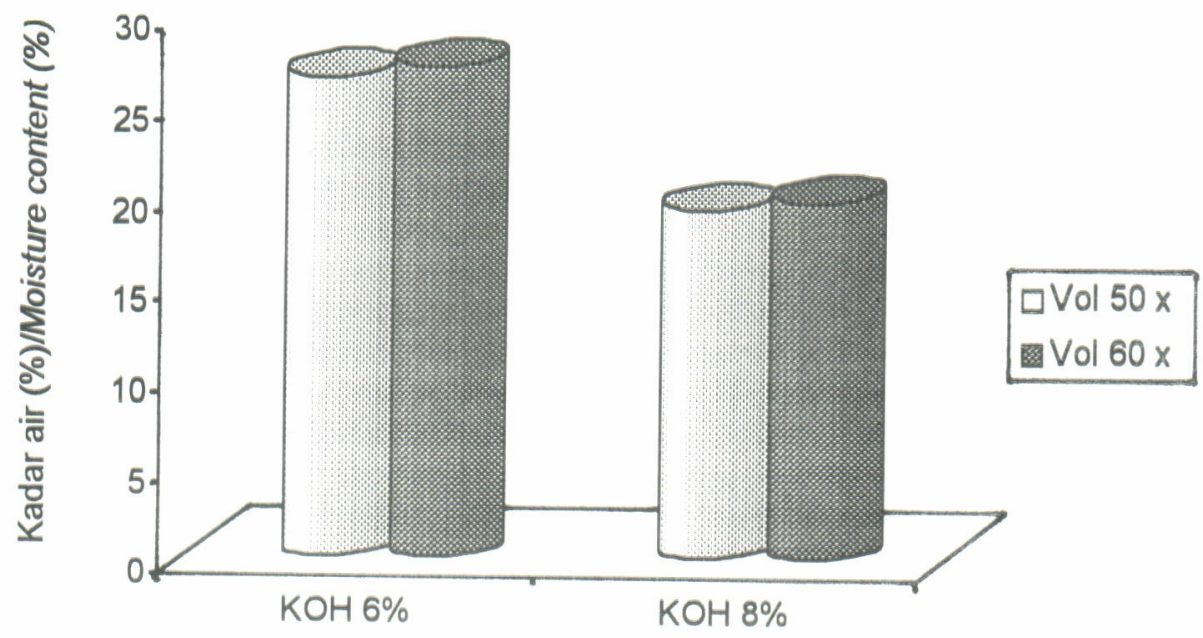

Gambar 4. Kadar air karaginan dari perlakuan konsentrasi KOH dan volume larutan pengekstrak yang berbeda Figure 4. Moisture content of carrageenan resulted from different concentration of $\mathrm{KOH}$ and volume of extraction water 
distandarkan yaitu $12 \%$. Oleh karena itu pengeringan karaginan perlu diperpanjang waktunya sehingga diperoleh tingkat kekeringan yang memenuhi standar.

\section{Kadar abu}

Pengaruh perlakuan alkali dan volume larutan pengekstrak terhadap kadar abu karaginan dapat dilihat pada Gambar 5. Hasil analisis statistik menunjukkan bahwa kadar abu karaginan yang karaginan dalam penelitian ini berkisar antara 14,06 $15,11 \%$ sedangkan uji kemurnian tepung karaginan yang disyaratkan oleh FAO adalah sebesar $15-40 \%$.

\section{Kadar abu tak larut asam}

Kadar abu tak larut asam karaginan hasil penelitian ini berkisar antara $0,12-0,43 \%$, kadar ini jauh di bawah standar maksimum tepung karaginan yang dikeluarkan oleh $\mathrm{FAO}$ yaitu sebesar $2 \%$. Rendahnya

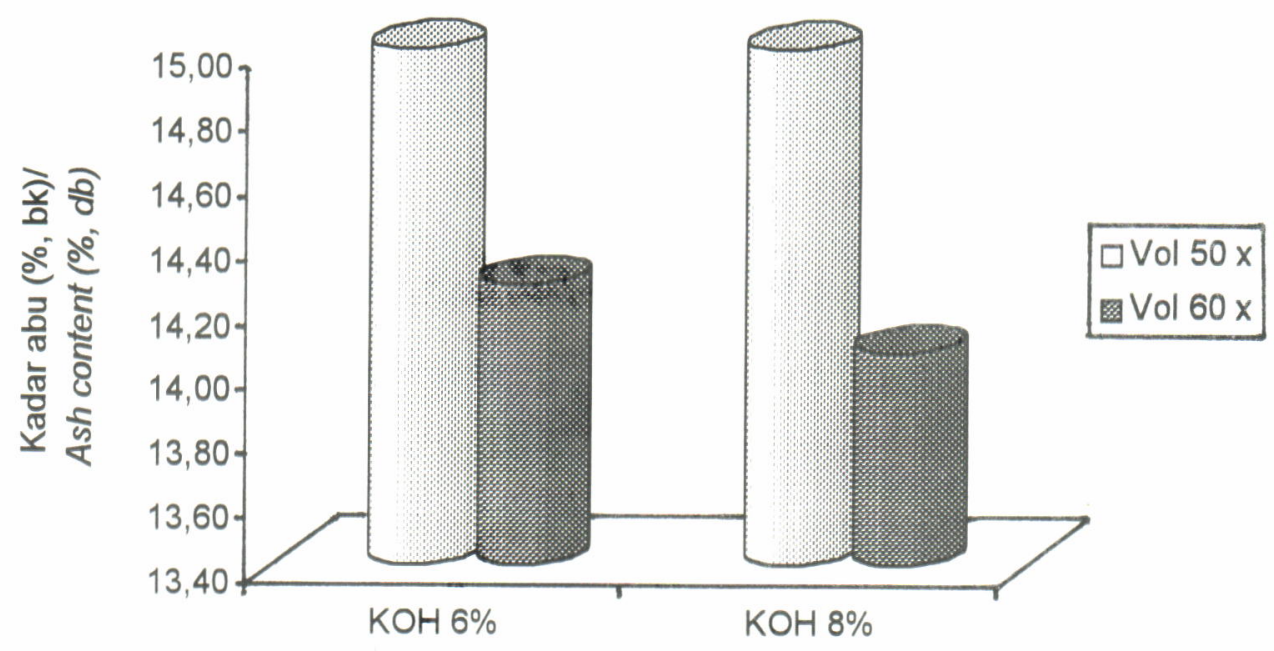

Gambar 5. Kadar abu karaginan dari perlakuan konsentrasi $\mathrm{KOH}$ dan volume larutan pengekstrak yang berbeda

Figure 5. Ash content of carrageenan resulted from different concentration of $\mathrm{KOH}$ and volume of extraction water

diektrak dari rumput laut yang diberi perlakuan $\mathrm{KOH}$ $6 \%$ dan $8 \%$ jika diekstrak dengan volume larutan pengekstrak 50 kali tidak berbeda nyata. Namun jika diekstrak dengan volume pengekstrak 60 kali dengan perlakuan $\mathrm{KOH} 8 \%$, menghasilkan kadar abu yang lebih rendah. Kadar abu pada karaginan dapat dikaitkan dengan kandungan sulfatnya. Terlihat bahwa karaginan yang diperoleh dari rumput laut yang telah diberi perlakuan $\mathrm{KOH} 8 \%$ kadar abunya lebih rendah bila dibanding dengan perlakuan $\mathrm{KOH} 6 \%$. Semakin besar kadar sulfat karaginan yang dihasilkan semakin besar pula kadar abunya. Hal ini karena pada proses pengabuan beberapa sulfat akan menguap menjadi $\mathrm{SO}_{3}$ dan lainnya akan menjadi mineral atau oksida yang tidak menguap selama pengabuan (Anonymous 1978).

Volume larutan pengekstrak 60 kali menghasilkan karaginan dengan kadar abu yang lebih rendah dibandingkan dengan yang diekstraksi dengan volume larutan pengekstrak 50 kali. Kadar abu tepung kadar abu tak larut asam ini menunjukkan bahwa karaginan hasil ekstraksi rumput laut tidak terkontaminasi selama proses pengolahan. Hasil analisis statitistik terhadap kadar abu tak larut asam karaginan menunjukkan bahwa perlakuan yang diberikan berpengaruh nyata terhadap kadar abu yang dihasilkan $(P<0,05)$. Kadar abu tak larut asam yang diperoleh dari karaginan yang diekstraksi dari rumput laut yang diberi perlakuan $\mathrm{KOH} 6 \%$ dengan volume larutan pengekstrak 50 kali adalah yang paling tinggi dan berbeda nyata dengan perlakuan lainnya. Sedangkan rumput laut yang diberi perlakuan $\mathrm{KOH}$ $8 \%$ dengan volume pengekstrak 60 kali menghasilkan kadar abu tak larut asam yang paling rendah seperti terlihat pada Gambar 6.

\section{Kadar sulfat}

Perlakuan konsentrasi $\mathrm{KOH}$ dan volume larutan pengekstrak terhadap kadar sulfat karaginan dapat dilihat pada Gambar 7. Hasil analisis statistik 


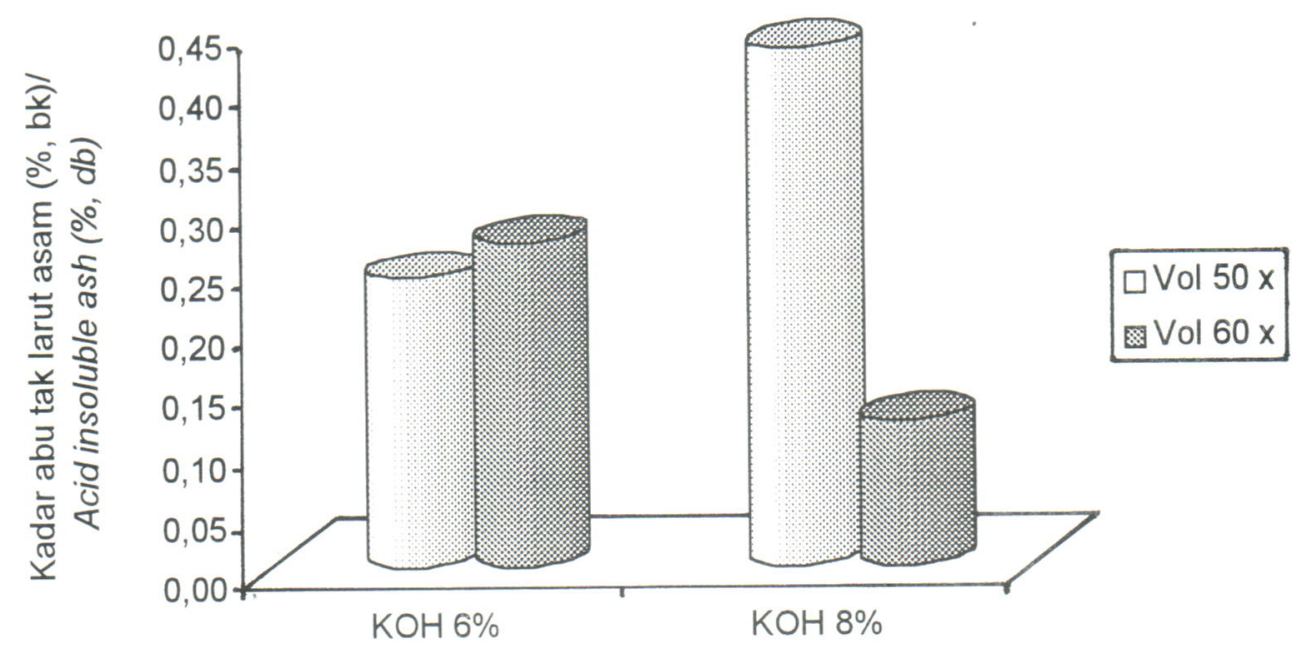

Gambar 6. Kadar abu tak larut asam dari perlakuan konsentrasi KOH dan volume larutan pengekstrak yang berbeda

Figure 6. Acid insoluble ash content of carrageenan resulted from different concentration of $\mathrm{KOH}$ and volume of extraction water

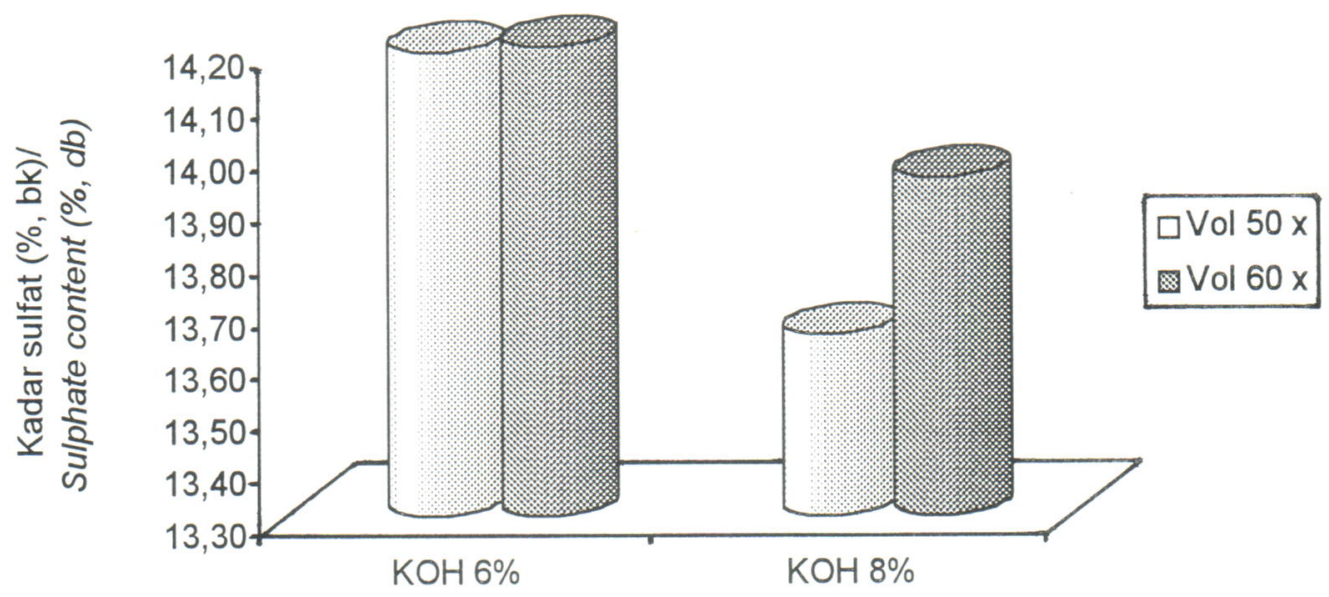

Gambar 7. Kandungan sulfat karaginan dari perlakuan konsentrasi KOH dan volume larutan pengekstrak yang berbeda

Figure 7. Sulphate content of carrageenan resulted from different concentration of $\mathrm{KOH}$ and volume of extraction water

menunjukkan bahwa perlakuan yang diberikan tidak berpengaruh terhadap kadar sulfat karaginan yang dihasilkan $(P>0,05)$.

Rata-rata kandungan sulfat karaginan yang diekstrak dari rumput laut yang diberi perlakukan $\mathrm{KOH}$ $6 \%$ adalah $14,19 \%$. Nilai ini sedikit lebih tinggi bila dibandingkan dengan kandungan sulfat yang diperoleh dari rumput laut yang diberi perlakuan $\mathrm{KOH} 8 \%$ yaitu sebesar $13,80 \%$. Sedangkan rata-rata kandungan sulfat karaginan yang diekstrak dari rumput laut yang diberi perlakuan $\mathrm{KOH} 8 \%$ dengan volume larutan pengekstrak 50 kali adalah sebesar $13,65 \%$ dan 


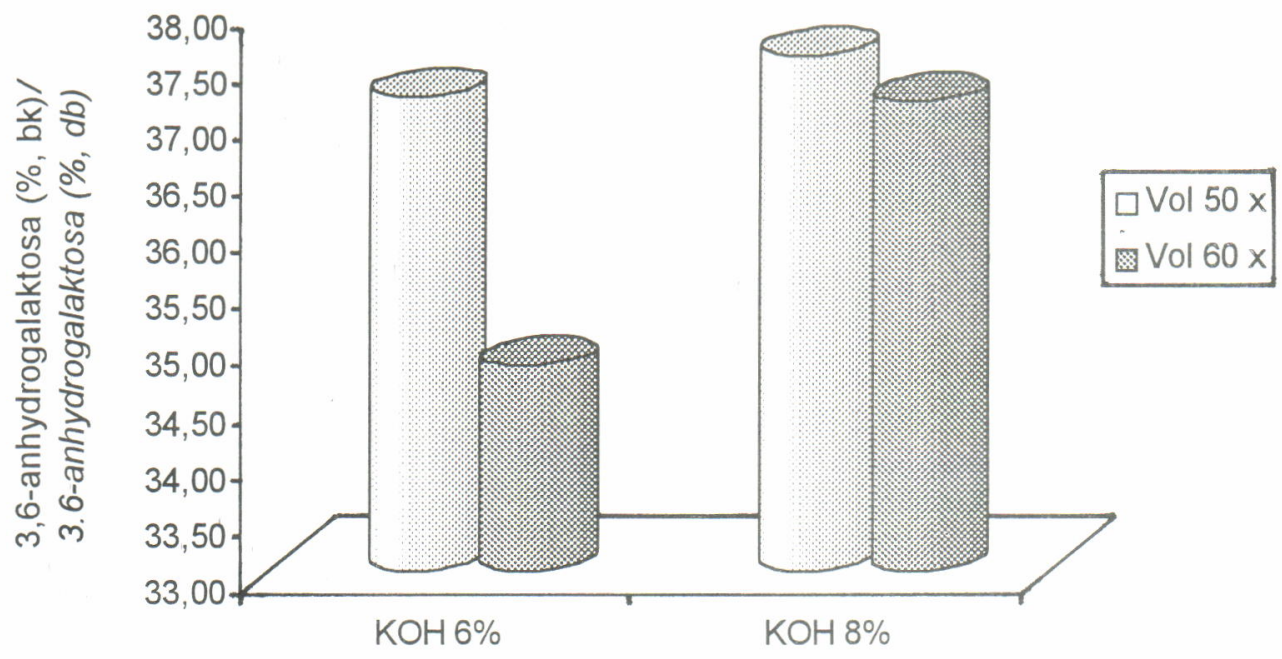

Gambar 8. Kandungan 3,6-anhydrogalaktosa dari perlakuan konsentrasi $\mathrm{KOH}$ dan volume larutan pengekstrak yang berbeda

Figure 8. 3.6-anhydrogalaktosa content of carrageenan resulted from different concentration of $\mathrm{KOH}$ and volume of extraction water

tidak berbeda dengan perlakuan volume larutan pengekstrak 60 kali yaitu sebesar 13,95\%. Pada penelitian ini kandungan sulfat terendah diperoleh pada karaginan yang diekstrak dari rumput laut yang telah diberi perlakuan $\mathrm{KOH} 8 \%$ dan diekstrak menggunakan volume larutan pengekstrak 50 kali. Kandungan sulfat karaginan yang diperoleh pada penelitian ini sedikit di bawah standar kandungan sulfat karaginan yang dikeluarkan oleh FAO yaitu sebesar $15-40 \%$ (Anonymous, 1986).

\section{3,6-anhydrogalaktosa}

Rata-rata kandungan 3,6-anhydrogalaktosa karaginan yang diperoleh dari percobaan ini berkisar antara $34,82-38,74 \%$ seperti disajikan pada Gambar 8. Hasil analisis statistik menunjukkan bahwa perlakuan yang diberikan berpengaruh nyata pada kandungan 3,6-anhydroglaktosa $(P<0,05)$. Kandungan 3,6-anhydrogalaktosa pada karaginan yang diekstrak dari rumput laut yang telah diberi perlakuan $\mathrm{KOH} 6 \%$ dan volume larutan pengekstrak 60 kali paling rendah $(34,82 \%)$ dan berbeda nyata dengan perlakuan lainnya. Sedangkan kandungan 3,6-anhydrogalaktosa karaginan yang diekstrak dari rumput laut yang diberi perlakuan $\mathrm{KOH} 6 \%$ dengan volume larutan pengekstrak 50 kali tidak berbeda nyata dengan yang diekstrak dari rumput laut yang diberi perlakuan $\mathrm{KOH} 8 \%$ baik dengan volume larutan pengekstrak 50 kali maupun 60 kali.
Rata- rata kandungan 3,6-anhydrogaktosa karaginan yang diekstrak dari rumput laut yang diberi perlakuan $\mathrm{KOH} 8 \%$ adalah $37,36 \%$ tidak berbeda dengan rata-rata kandungan 3,6-ahnydrogalaktosa karaginan yang diekstrak dari rumput laut yang diberi perlakuan $\mathrm{KOH} 6 \%$ yaitu sebesar $36,78 \%$. Uji Duncan menunjukkan bahwa kandungan 3,6anhydrogalaktosa karaginan hanya berbeda nyata pada perlakuan volume larutan pengekstrak 60 kali pada rumput laut yang diberi perlakuan $\mathrm{KOH} 6 \%$. Pada perlakuan ini kandungan 3,6-anhydrogalaktosa paling rendah dibandingkan dengan yang lainnya yaitu sebesar $34,82 \%$.

\section{Sifat Fisik Karaginan}

\section{Kekuatan gel karaginan}

Pengaruh perlakuan bahan baku dan volume larutan pengekstrak terhadap kekuatan gel karaginan yang dihasilkan dapat dilihat pada Gambar 9.

Hasil analisis statistik menunjukkan bahwa perlakuan yang diberikan tidak berpengaruh nyata terhadap kekuatan gel yang dihasilkan $(P>0,05)$. Rumput laut yang diberi perlakuan $\mathrm{KOH} 6 \%$ mempunyai kekuatan gel yang berkisar antara 1.148$1.156 \mathrm{~g} / \mathrm{cm}^{2}$ sedangkan rumput laut yang diberi perlakuan $\mathrm{KOH} 8 \%$ sebesar $801-932 \mathrm{~g} / \mathrm{cm}^{2}$. Dalam proses perlakuan alkali pada rumput laut, interaksi 
antara suhu perebusan, waktu perebusan dan konsentrasi alkali merupakan parameter yang saling berinteraksi dalam menentukan tingkat kekuatan gel karaginan yang dihasilkan. Hasil penelitian Istini dan Zatnika (1991) menunjukkan bahwa untuk konsentrasi $\mathrm{KOH} 8 \%$, waktu yang diperlukan untuk menghasilkan kekuatan gel tertinggi adalah 3 jam dengan suhu pemasakan $80^{\circ} \mathrm{C}$ sedangkan menurut Stanley (1987) suhu $90-95^{\circ} \mathrm{C}$ adalah suhu optimal untuk mendapatkan kekuatan gel yang paling baik.

Penggunaan larutan $\mathrm{KCL} 0,1 \%$ untuk proses ekstraksi menyebabkan gel kappa-karaginan yang dihasilkan dari rumput laut Eucheuma cottonii bersifak kaku (Anonymous, 2002), meskipun gel yang dihasilkan keras tetapi tidak bersifat elastis. Pada saat pengukuran dengan menggunakan curd meteryang diberi beban tertentu, gel mudah pecah dan nilai yang dihasilkan rendah. Kekuatan gel karaginan semakin menurun pada karaginan yang diekstrak dari rumput laut yang diberi perlakuan alkali $\mathrm{KOH} 8 \%$ dengan volume larutan pengekstrak 50 kali. Hal ini mungkin disebabkan adanya fragmentasi polisakarida selama proses ekstraksi. Karaginan yang diperoleh dari volume pengekstrak 50 kali mempunyai $\mathrm{pH}$ yang lebih tinggi, sehingga menghasilkan karaginan dengan bobot molekul yang lebih kecil.

Proses ekstraksi dengan alkali dalam penelitian ini mampu meningkatkan kekuatan gel karaginan yang dihasilkan sampai di atas $800 \mathrm{~g} / \mathrm{cm}^{2}$. Kekuatan gel karaginan di pasaran dikatakan baik apabila di atas $1.000 \mathrm{~g} / \mathrm{cm}^{2}$ (Anonymous, 2002). Dalam penelitian ini kekuatan gel karaginan dapat mencapai di atas $1.000 \mathrm{~g} / \mathrm{cm}^{2}$ apabila diekstrak dari rumput laut yang diberi perlakuan $\mathrm{KOH} 6 \%$. Namun demikian kekuatan gel ini jauh lebih tinggi dibandingkan dengan kekuatan gel karaginan hasil ekstraksi rumput laut tanpa perlakuan alkali yang dilakukan oleh peneliti lain. Hasil penelitian Murdinah et al (2003) menunjukkan bahwa karaginan yang diekstraksi dengan soda abu $0,5 \%$ kemudian dijendalkan dengan $\mathrm{KCL} 3 \%$ menghasilkan kekuatan gel sebesar $193 \mathrm{~g} / \mathrm{cm}^{2}$. Namun bila karaginan diekstraksi dengan $\mathrm{NaOH}$ kemudian diendapkan dengan iso propil alkohol menghasilkan kekuatan gel $242 \mathrm{~g} / \mathrm{cm}^{2}$.

\section{Kekentalan}

Kekentalan larutan karaginan yang diperoleh dari berbagai perlakuan dapat dilihat pada Gambar 10. Hasil analisis statistik menunjukkan bahwa perlakuan yang diberikan berpengaruh nyata $(P<0,05)$ terhadap kekentalan larutan karaginan. Larutan karaginan yang diperoleh dari bahan rumput laut yang diberi perlakuan alkali $\mathrm{KOH} 6 \%$ lebih kental bila dibandingkan dengan yang diperoleh dari perlakuan $\mathrm{KOH} 8 \%$. Kekentalan larutan karaginan selain ditentukan oleh suhu, konsentrasi, tipe karaginan, adanya ion logam juga

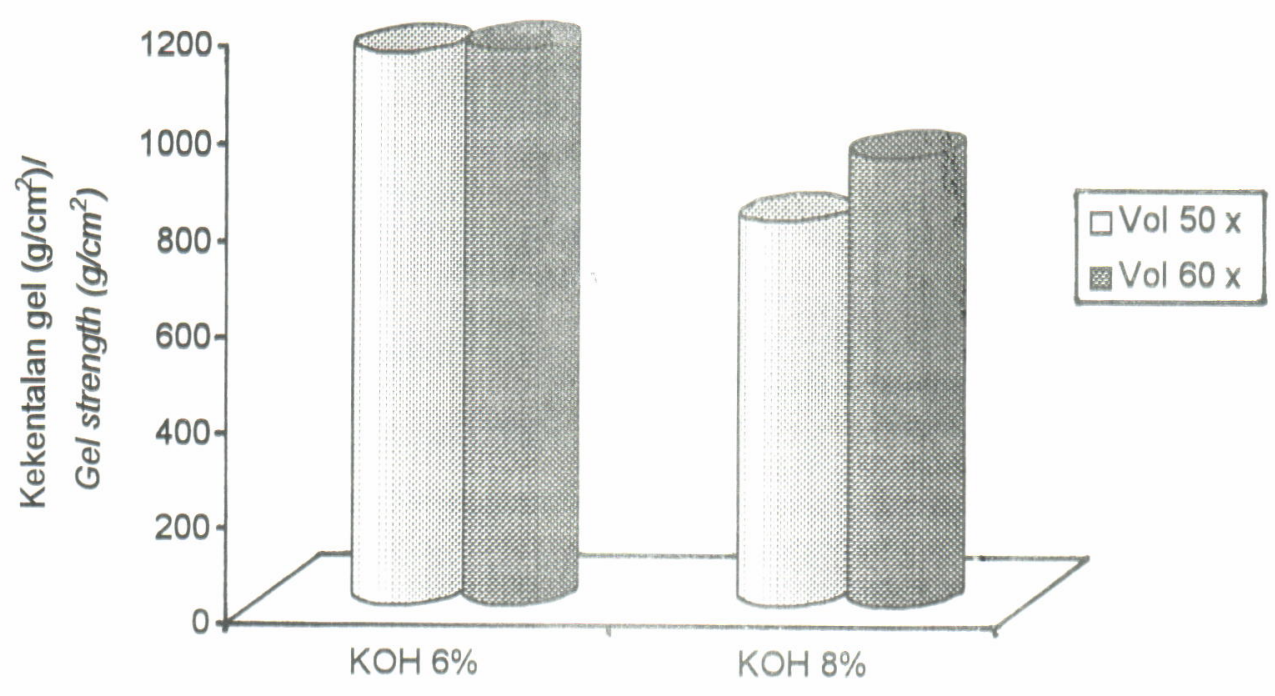

Gambar 9. Kekuatan gel karaginan dari perlakuan konsentrasi $\mathrm{KOH}$ dan volume larutan pengekstrak yang berbeda

Figure 9. Gelstrength of carrageenan resulted from different concentration of $\mathrm{KOH}$ and volume of extraction water 


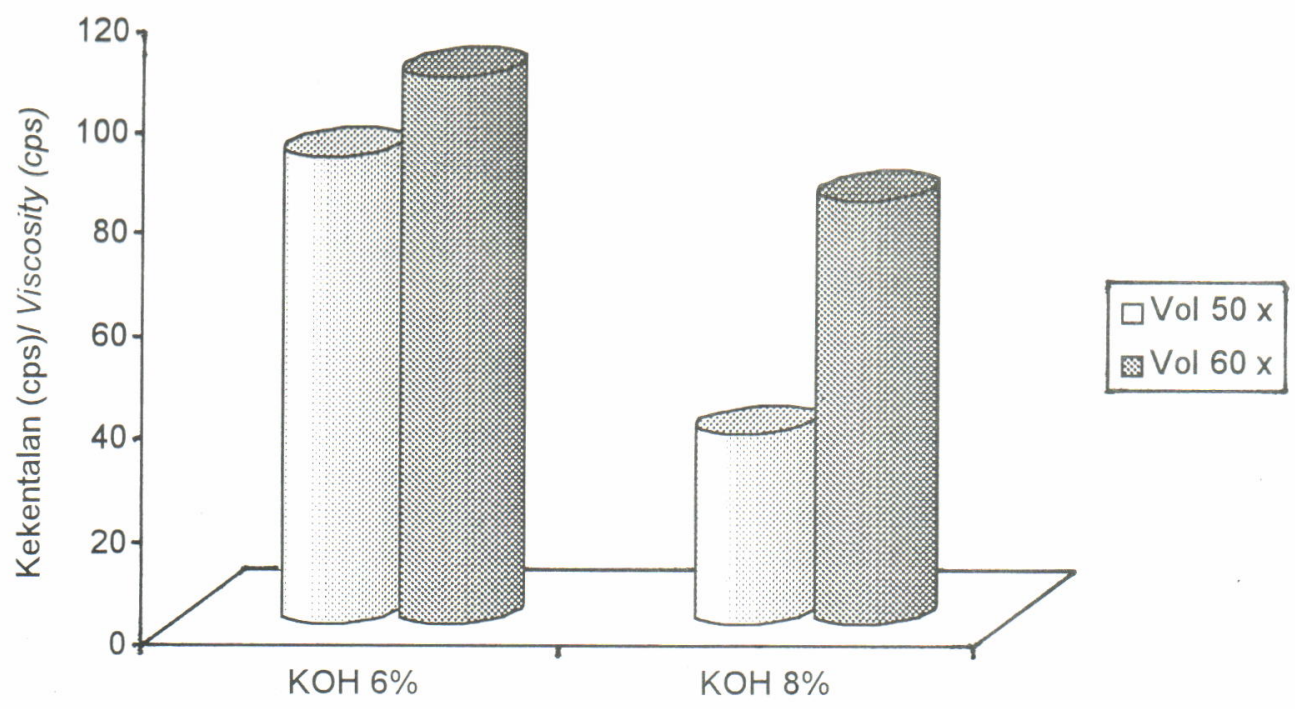

Gambar 10. Kekentalan larutan karaginan dari perlakuan konsentrasi $\mathrm{KOH}$ dan volume larutan pengekstrak yang berbeda

Figure 10. Viscosity of carrageenan solution resulted from different concentration of $\mathrm{KOH}$ and volume of extraction water

oleh bobot molekul (Stanley, 1987). Kekentalan larutan karaginan bertambah dengan bertambahnya bobot molekul karaginan. Semakin besar bobot molekul karaginan semakin besar pula kekentalan karaginan yang dihasilkan. Rendahnya kekentalan larutan karaginan yang diperoleh dari rumput laut yang diberi perlakuan $\mathrm{KOH} 8 \%$ semakin memperjelas kemungkinan terjadinya fragmentasi pada proses alkali yang berakibat menurunnya bobot molekul karaginan. Terlihat bahwa karaginan yang diekstraksi dengan menggunakan volume larutan pengekstrak 50 kali kekentalannya lebih rendah dibandingkan dengan karaginan yang diekstrak dengan volume larutan pengekstrak 60 kali. Hal ini disebabkan dengan semakin kecil volume larutan pengekstrak maka semakin besar kemungkinan terjadinya proses fragmentasi yang berakibat semakin kecilnya bobot molekul karaginan yang dihasilkan. Kecilnya bobot molekul tersebut menyebabkan semakin rendahnya nilai kekentalan larutan karaginan yang dihasilkan.

Hasil uji Duncan menunjukkan bahwa rata-rata kekentalan larutan karaginan yang diekstrak dari rumput laut yang diberi perlakuan $\mathrm{KOH} 8 \%$ dengan volume larutan pengekstrak 50 kali menghasilkan kekentalan yang paling rendah dan berbeda nyata dengan perlakuan lainnya. Sedangkan kekentalan larutan karaginan dari rumput laut dengan perlakuan $\mathrm{KOH} 6 \%$ dengan volume larutan pengekstrak 50 kali dan 60 kali tidak berbeda nyata dengan perlakuan
$\mathrm{KOH} 8 \%$ dan volume larutan pengekstrak 60 kali. Pada penelitian ini kekentalan yang diukur dari larutan $1,5 \%$ pada suhu $75^{\circ} \mathrm{C}$ berkisar antara 37-112 cps dan masih berada dalam kisaran larutan karaginan komersial yaitu berkisar antara 5-800 cps. Namun demikian pada umumnya karaginan yang ada di pasaran mempunyai kekentalan di atas $150 \mathrm{cps}$ (Anonymous, 2002)

\section{KESIMPULAN DAN SARAN}

Dari hasil penelitian ini dapat disimpulkan bahwa ektraksi karaginan dengan menggunakan bahan rumput laut yang telah diberi perlakuan $\mathrm{KOH} 8 \%$ menghasilkan karaginan dengan kadar air, kadar abu, kadar abu tak larut asam yang lebih mendekati standar karaginan yang dikeluarkan oleh FAO dibandingkan dengan perlakuan $\mathrm{KOH} 6 \%$. Rumput laut yang diberi perlakuan $\mathrm{KOH} 6 \%$ menghasilkan rendemen dan kekentalan yang lebih baik jika di ektraksi dengan volume larutan pengekstrak 60 kali, tetapi jika diekstraksi dengan menggunakan volume larutan 50 kali hasilnya tidak berbeda nyata. Sedangkan perlakuan alkali terhadap bahan mentah rumput laut dan volume larutan pengekstrak yang diberikan tidak berpengaruh nyata terhadap kadar sulfat dan kekuatan gel yang dihasilkan.

Dari hasil penelitian ini dapat disarankan jika rendemen dan kekuatan gel diprioritaskan maka lebih 
baik dipilih perlakuan $\mathrm{KOH} 6 \%$ dan diekstraksi dengan

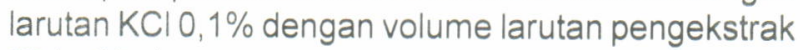
60 kali bobot rumput laut kering

\section{DAFTAR PUSTAKA.}

Anonymous. 1986. Specification for Identify and Purity of Certain Food Additives. FAO and Nutrition Paper, No $34: 17-22$

Anonymous. 1977. Raw Material Test Laboratory Standard Practice. Marine Colloids Div. Corp. Springfield. New Yersey. USA. $42 \mathrm{pp}$.

Anonymous. 1978. Carrageenan. The Copenhagen Pectin Factory LTD. A/S Kobenhagen Pectifabrik Denmark. $48 \mathrm{pp}$.

Annonymous. 1996. An Introduction to Carrageenan. http/ /phikoexport. org/members/ siap/intro.htm. 14 pp.

Anonymous, 2000. Semi Refined Carrageenan. Industry Overview. Holdiko Perkasa. $4 \mathrm{pp}$.

Anonymous. 2001. Statistik Perikanan Tangkap Indonesia 2000. Departemen Kelautan dan Perikanan. Dit Jen Perikanan Tangkap. 94 pp

Anonymous, 2002. Kappa Carrageenan Flake. Shishi Fujun Food Co LTD. 1 pp.

Anonymous, 2003. Carrageenan. FMC Marine Colloids. New Yersey USA. 13 pp.

AOAC. 1984. Official Method of Analysis of the Associates of official Analytical chemist. $14 \mathrm{ed}^{\text {th }}$ A.O.A.C. Inc Arlington Virginia.
Basmal, J. 2000. Prospek Industri Rumput Laut Eucheuma sp Penghasil Semi Refine Karaginan dan Refine Karaginan. Makalah disampaikan pada Temu Bisnis Industri Pengolahan Rumput Laut. Puslitbang Perikanan. $11 \mathrm{pp}$

Chaplin, M. 2003. Carrageenan. http//www.sbu.ac.uk/ water/hycar.html. 3 pp.

Chapman, V.J. and Chapman, D.J. (1980). Seaweeds and Their Uses. Third Edition. Chapman Hall, London. N. Y.

Istini, S dan Zatnika, A. 1991. Optimasi Proses Semirefine carrageenan dari rumput laut Eucheuma cottonii. Prosiding Temu Karya Ilmiah Teknologi Pasca Panen Rumput Laut Buku II. Pusat Penel. dan Pengembangan Perikanan Balitbang Pertanian Dept. Pertanian. Jakarta. p. 87-100.

Murdinah, Erlina, M.D., Dwi Suryaningrum,Th., Agus Heri Purnomo, Umi Rahayu, Yayat Sudrajat, Rusdi. 2003. Penelitian Ekstraksi karagianan Skala Semi Komersial. Laporan Teknis Pusat Riset Pengolahan Produk dan Sosial Ekonomi Kelautan dan Perikanan. Departemen Kelautan dan Perikanan. 140 pp

Neish, I.C. 1989. Alkali Treatment of Carrageenan Bearing Seaweeds Past, Present and Future. FMC Corporation, Marine Colloid Div. 11 pp.

Sandersen, G.R. 1981. Polysaccharides in foods. J. Food Technol. 35 (7). p. 50-59.

Stanley. N. 1987. Production, Properties and Uses of Carrageenan. In Mc Hugh, D.J. (ed). Production and Utilization of Products from Commercial seaweeds. FAO Fish Tech Paper. 288:116-146 